\title{
GEOLOGICAL AND ECONOMIC ASSESSMENT AND PROSPECTS OF DEVELOPMENT OF RARE METALS MINERAL RESOURCE BASE OF UKRAINE IN THE CURRENT ECONOMIC CONDITIONS
}

\section{ГЕОЛОГО-ЕКОНОМІЧНЕ ОБҐРУНТУВАННЯ ТА ПЕРСПЕКТИВИ РОЗВИТКУ МІНЕРАЛЬНО-РЕСУРСНОЇ БАЗИ РІАКІСНИХ МЕТАЛІВ УКРАЇНИ В СУЧАСНИХ ЕКОНОМІЧНИХ УМОВАХ}

\author{
Nataliya M. Cherniyenko \\ Н.М. Чернієнко \\ Institute of Geological Sciences, NAS of Ukraine, 55-b 0. Honchara Str., Kyiv, Ukraine, 01601 (nataly.kiev@i.ua)
}

The state of the productive forces in the mineral resource sector of Ukraine at the present stage of its political, economic and social development is determined by the characteristics of the mineral resource base, export-import state policy, market relations and economic priorities state, as well as the ability to meet the raw material needs from its own mineral resources on the basis of the latest achievements of scientific and technical progress in the development and implementation of low- and non-waste technology in mining and processing of natural and man-made mineral resources. The perspectives of development of rare metals and rare-earth minerals resource base in Ukraine are presented on the example Perzhansk Ore District, Tarasivka, Mazurivka and Mokroyalynka deposits. Rare metals and rare earth elements are found in a wide range of products, which have economic and strategic importance. They are an indicator of the level of scientific and technological development of the country in the modern world. Advanced development of rare metal industry can give a significant economic impact by reducing energy and material consumption, ensure the development of the mining industry, provide a way out of the present doldrums of some regions of Ukraine and their economic development for many decades.

Keywords: Ukrainian Shield, Sushchano-Perzhansk activation zone, Perzhansk Ore District, Mazurivka deposit, alkaline metasomatic rocks, syenite, strategic reserves, rare metals, rare earth elements, placers.

Стан виробничих сил в мінерально-сировинному комплексі України на сучасному етапі ії політичного, економічного і соціального розвитку визначається особливостями мінерально-сировинної бази, спрямованістю експортно-імпортної політики держави, станом ринкових відносин і економічними пріоритетами, а також можливістю задовольняти сировинні потреби за рахунок власних мінеральних ресурсів на основі новітніх досягнень науково-технічного прогресу в галузі створення і впровадження мало- і безвіАходних технологій при видобутку, збагаченні, переробці природних і техногенних видів мінеральної сировини. На прикладі Пержанського рудного району, Тарасівського, Мазурівського, Мокроялинського родовищ розгяннуто перспективи розвитку мінерально-сировинної бази ріАкісних металів та рідкісних земель в Україні. РіАкісні метали та рідкоземельні елементи містяться в широкому спектрі продуктів, що мають економічне і стратегічне значення. В сучасному світі вони є показником науково-технічного рівня розвитку країни. ВипереАжаючий розвиток ріАкіснометалевої промисловості спроможний Аати значний економічний ефект за рахунок скорочення енерго- і матеріаловитрат, забезпечити розвиток гірничодобувної промисловості, забезпечити вихіА із сучасного Аепресивного стану окремих регіонів України та їх економічний розвиток протягом багатьох Аесятиліть.

Ключові слова: Український щит, Сущано-Пержанська зона активізації, Пержанський рудний район, Мазурівське родовище, лужні метасоматити, сієніти, стратегічні матеріали, рідкісні метали, ріАкісні землі, родовища, розсипи.

\section{INTRODUCTION}

Mineral resources and mining and industrial production will continue to maintain their position in the basic structure of the world economy (Cherniyenko, 2008, 2013; Galets'kyi and Cherniyenko, 2008; Galets'kyi et al., 2009, 2012, 2015; Gurskyi et al., 2005). In the current economic conditions particular attention is paid to rare and rare earth metals. The range of rare earth products has more than 400 items. High-tech modern productions developed on their basis. They are used in leading industries and provides economic and defensive security of any state. The largest consumers of rare metals are USA, Japan, Western Europe, Australia.
Japan has adhered to the strategy of austerity and does not have at its disposal own rare metals raw materials, however, has the highest rate of growth of consumption of rare metals. In its list of «important materials of the future" a significant part of material involves the rare metals. Eleven rare metals and rare earth elements in the United States are attributed to strategic materials: $\mathrm{V}, \mathrm{Be}, \mathrm{Hf}, \mathrm{Ge}, \mathrm{Cd}$, $\mathrm{Nb}, \mathrm{Sr}, \mathrm{Ta}, \mathrm{Te}, \mathrm{Zr}$, TR. For this group of metals the US government in 1939 launched the development of strategic reserves. In Ukraine rare metals and rare earth mineral resource potential is the largest in Europe: $\mathrm{Zr}, \mathrm{Hf}, \mathrm{TR}, \mathrm{Be}, \mathrm{Li}, \mathrm{Nb}, \mathrm{Ta}, \mathrm{Sc}, \mathrm{V}, \mathrm{Ga}, \mathrm{Ge}, \mathrm{Sn}$, Mo, etc. Commercially there is a manufacture of 
zirconium products. At the same time there are opportunities of attraction in development of ores niobium, tantalum, beryllium, lithium, rare earths and other (Cherniyenko, 2008, 2013; Galets'kyi and Cherniyenko, 2008; Galets'kyi et al., 2012, 2015).

Comprehensive and rational use of mineral resources of Ukraine to ensure stable development of the economy, increase of rare metals and rare earths mineral resource potential is the main goal of the researches. Rare metals and rare earths deposits and ore occurrences within the Ukrainian shield were the objects of study.

\section{MATERIALS, METHODS AND METHODOLOGY}

Complex of modern methods, including geological, structural, metallogenic prognostic, geophysical, geochemical, mineralogical, geological technological, geological economic studies, was used to solve the task. Generalization of the available factual data of geological survey and exploration related to the potential rare ore objects within the Ukrainian shield was the initial stage of research. Complex geologicalstructural and metallogenic analysis have been performed to determine the conditions for the development and localization of rare ores, study the deep structure of ore bodies. Details of ores petrochemical and mineral composition were studied. Geological and economic parameters for commercial development of mining objects were determined. Digital models of Mazurivka and Perzhansk deposits, providing optimal algorithm for their industrial development, have been created on the base of geological data. In order to make minimum impact on the environment, considering the possible geological and environmental effects, the new terms of deposits development have been offered.

The results of research, conducted by the Institute of Geological Sciences of Ukraine with the direct participation of the author, together with the "Pivdenukrgeologiya", "Zhytomyr geological expedition", enterprise allowed identifying the promising targets, among which there are unique and large deposits. The analysis of exploration data, geological and economic evaluation of rare metals and rare earth potential allows us to identify priority perspective sites for the development.

\section{THE RESULTS AND ANALYSIS}

Within the Ukrainian Shield there are three rare-metal districts: Northwest, Central, Near-Azov (Southeast). It is identified 22 rare-metal formations here, formed mainly due to the Early Proterozoic mobile belts and the Late Proterozoic superimposed zones of tectonic-magmatic and tectonic-metasomatic activation, within which granitoid and alkaline magmatism, pegmatite and metasomatic processes are revealed. There is highlighted a number of ore formations in connection with ore-bearing weathering crusts and placers. The complex deposits are of great interest in connection with rare-metal granites, subalkalic granites and syenites substituted by pegmatites and alkaline metasomatic rocks. Almost all of them are deposits of a complex type (Atlas, 2007; Cherniyenko, 2008, 2013; Galets'kyi et al., 2012).

In the north-western part of the Ukrainian Shield we have studied Perzhansk rare metal Ore District. Its formation is associated with the node intersection Sushchano-Perzhansk activation zone of northeast trending and North-Ukrainian Megazone ore concentration of latitudinal direction (Galets'kyi et al., 2012; Galets'kyi and Romaniuk, 2011; Gurskyi and Chornokur, 2009; Naumenko, 2014; Romaniuk, 2013; Romaniuk and Cherniyenko, 2013; Vysotskyi et al., 2003).

The central part of Sushchano-Perzhansk activation zone is characterized by significant ore bearing. In geological terms, it is a tectonic block with different crystalline rocks and ore mineralization: granite with late vein complex that has genthelvite and fluorite mineralization; gabbroid of ilmenite, apatite and titan magnetite mineralization; syenite with rare-metal and rare-earth mineralization; schists and quartzites of kyanite mineralization (Galets'kyi et al., 2012, 2016; Gurskyi and Chornokur, 2009; Romaniuk, 2010, 2013; Romaniuk and Cherniyenko, 2013; Vysotskyi et al., 2003).

Rare metals mineralization is associated with Perzhansk complex of granite and syenite of Mesoproterozoic age, the main petrophone of which is Perzhansk rare-metal granites (apogranites) (Romaniuk, 2010). These granites are related to a new paragenetic type siderophyllite-K-feldsparperthitic apogranite of palengen-metasomatic genesis, which is formed in a linear tectonic activation zones. Productive rare metals mineralization of beryllium, niobium, tantalum, tin, tungsten, zirconium, lithium, rare earths associated with these granites. The main importance is the genthelvite (genthelvite $\left.\mathrm{Zn}_{4}\left(\mathrm{BeSi}_{2}\right)_{3} \mathrm{~S}\right)$ form of beryllium mineralization, with an average content of $\mathrm{BeO}-0,55 \%$, maximum $\mathrm{BeO}-$ $8-13 \%$, which refers to the highest-quality ores. Beryllium mineralization is localized in alkaline metasomatic rocks of microcline-pertit composi- 
tion, which are located in accordance with apogranites and genetically connected with them (Fig. 1) (Galets'kyi et al., 2012, 2016; Gurskyi and Chornokur, 2009; Romaniuk, 2010, 2013; Romaniuk and Cherniyenko, 2013; Vysotskyi et al., 2003).

The emergence of ore concentrations of beryllium and other trace elements is associated both with the penetration of deep fluids, and consistent mobilization and redistribution of the ore material in connection with long-term and large-scale metasomatic processes with the active participation of meadows and volatile components (Galets'kyi and Romaniuk, 2011; Gurskyi and Chornokur, 2009; Romaniuk, 2010; 2013).

Mineral composition of rocks within the Suschano-Perzhansk zone is very diverse and reflects the specific features of minerogenesis in the area. First of all, it is a wide development of regional and local multistage metasomatic processes related to tectonic-magmatic and tectonic-metasomatic activation structures. There are 125 ore and accessory minerals determined in the Sushchano-Perzhansk zone rocks. (Romaniuk, 2010; 2013). Such wide mineral diversity as well as presence of many generations of ore minerals (up to 3-5) and their large concentrations evidence about the powerful ore potential of the Perzhansk Ore District and allow attribute it to the classic most productive ore areas in the world (Galets'kyi et al., 2016; Romaniuk, 2013).

Within Sushchano-Perzhansk activation zone we investigated and studied a number of deposits and occurrences that form Perzhansk Ore District.
Among them Perzhansk large-scale beryllium deposit was explored in detail (the only in the world where beryllium is concentrated in genthelvite form). Yurivske apatite-ilmenite, Sushchansk disthene, Yastrebetsk zircon and rare-earth deposits previously estimated. Under study are promising Tsentralny fluorite occurrences; cassiterite and raremetal ("Quarry", "Western", "Miners") and rare-metal ore occurrences ("East-Yastrebetsk" etc.); raremetal placers and weathering crusts (Galets'kyi et al., 2012, 2016; Gurskyi and Chornokur, 2009; Romaniuk, 2013; Romaniuk and Cherniyenko, 2013; Vysotskyi et al., 2003).

The morphology of ore bodies determines the quarry development of Yurivsk, Sushchansk and Yastrebetsk deposits; mine working of Perzhansk and Central deposits. In the developing of Perzhansk Ore Districts as a source of rare-metal, titanium and other types of commercial products, it is advisable to start with Perzhansk and Yurivsk fields, connecting to them Yastrebetsk, Sushchansk, Central, placer and other deposits, to extent necessary volumes of exploration. By the comprehensive geological and economic evaluation of Perzhansk Ore Districts it is established the possibility of the development of highly efficient mining and processing complex (Galets'kyi et al., 2012, 2016; Gurskyi and Chornokur, 2009; Romaniuk, 2013; Vysotskyi et al., 2003). Complex mineralization of Perzhansk ore district with a big mineragenic potential provides its development high profitability on the basis of a single mining company. The right strategic approach in

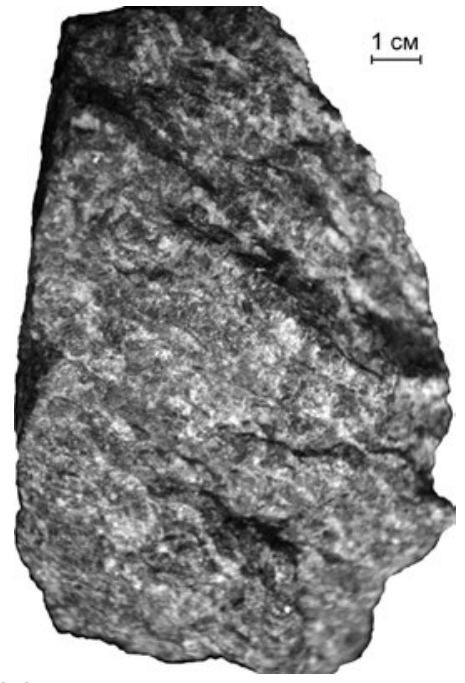

(a)

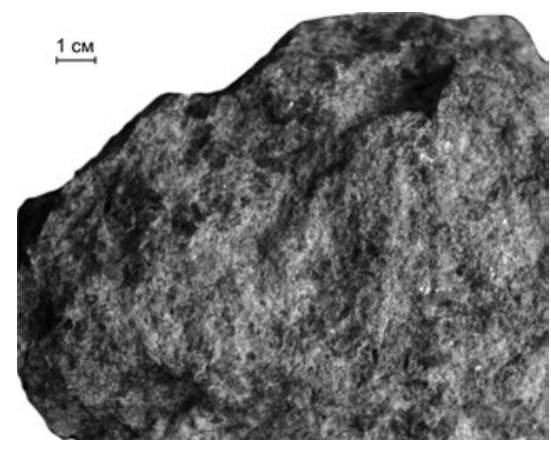

(b)

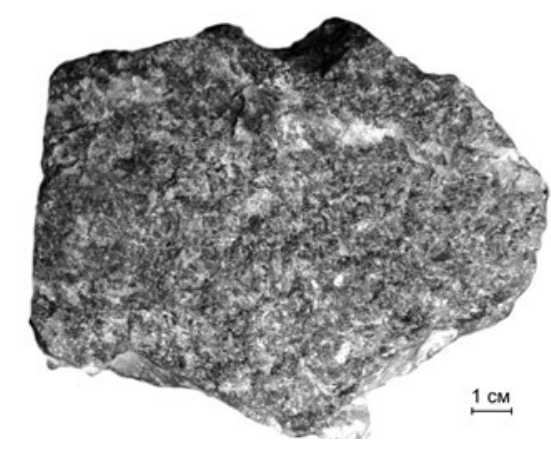

(c)

Fig. 1. Genthelvite metasomatic. Ores from underground mine workings (Galets'kyi et al., 2012). 
the development of Perzhansk Ore District is quite capable to provide economic development by decades according to the world experience (Galets'kyi et al., 2012, 2016).

Within the central part of Ukrainian Shield among the promising ore facilities are such: Tarasivka rutile-ilmenite-zircon deposit; Novopoltavka complex phosphorus-rare metal-rare earth ores deposit; Polokhivka, Stankovatka and Shevchenkiv lithium deposits associated with $\mathrm{Nb}$, Ta, Cs (Cherniyenko, 2013).

Tarasivka comprehensive placer (Cherniyenko, 2013; Galets'kyi et al., 2012; Gurskyi et al., 2005) rutile-ilmenite-zirconium deposit is located in the south western part of the Kiev region. Raw materials are represented by quartz sand with an average content of accessory minerals $2.2-2.4 \%$. The main industrial placer minerals: ilmenite, rutile, zircon and leucoxene. The overburden includes various clays and loams. The average thickness of the overburden is $18.5 \mathrm{~m}$. The deposit by the reserves of major components belongs to the category of the average with prospects of growth through additional exploration flanks of the field.

Tarasivka deposit is located within the central part of the Ukrainian Shield (Galets'kyi et al., 2012; Gurskyi et al., 2005). Crystalline rocks are mainly Lower Proterozoic granodiorites, diorites, migmatites and granites of Kirovohrad-Zhytomyr complex with rare xenoliths of Archean gneiss and amphibolites. The weathering crust of crystalline rocks is developed everywhere, and at the average is about $15 \mathrm{~m}$. The formation of crust occurred in Paleozoic-Cenozoic time. The sedimentary rocks of Paleogene and Neogene are overlying the eroded surface of the weathering crust, or directly to the crystalline rocks. There are Buchaksky, Kyiv and Kharkiv Paleogene series, Poltava series and Sarmatian Neogene stage. The last are overlapped by a thick (48 m) Quaternary formations: clay, loam, quartz sand, forests, and soil layer. Ore-bearing fine-grained sand of the Tarasivska deposit is concentrated in sediments of Novopetrivska suite of the Poltava series that are throughout the deposit area and contain titanium and zirconium minerals in industrial concentrations. On the south side the Poltava sands are eroded by the ancient bed of Tarhan river and Ros river on the west. In the north and east the sand of Poltava series extends beyond the field. The thickness of deposits in this series ranges from 0,3 to $40 \mathrm{~m}$ (average $-20 \mathrm{~m}$ ). Their occurrence is mainly subhorizontal with a decrease in the east and north-east (Galets'kyi et al., 2012; Gurskyi et al., 2005).

Among the deposits of Novopetrivska suite there are three horizons: the upper, middle and lower. The upper horizon of the field is developed everywhere and represented by poorly concentrated sandstones, small- and medium grained quartz sand with the light gray or yellowish kaolin. The thickness of sands is up to $16,9 \mathrm{~m}$. The average horizon has the same distribution and is composed mainly of fine-grained sand of light colour with the thickness of $0,5-30 \mathrm{~m}$. The sand of this horizon is characterized by different types of bedding - horizontal, oblique and wavy. The lower horizon is found mainly in the western and eastern parts of the field. It is composed of gray and greenish-gray bad rounded quartz sand. Dark green clay of Kharkiv series is the basis of the lower sand horizon (Galets'kyi et al., 2012; Gurskyi et al., 2005).

Industrial concentrations of titanium and zirconium minerals are confined to sandy sediments of the middle horizon. They stand in contrast as placer (productive strata) of sublatitudinal stretch of $25 \mathrm{~km}$ and width of $10-12 \mathrm{~km}$. In the section the placer is divided into two layers, which in the southwestern part of the deposit merge into the one.

The top placer layer is the main industry ore body as it contains up to $90 \%$ of balance reserves of metals. The thickness of the layer $-2,0-20,7 \mathrm{~m}$, the area of distribution - about $78,5 \mathrm{~km}^{2}$. The overburden thickness - 1,5-52,4 m (average linear coefficient of overburden $-4,88$ ), and for the explored part $-16,0 \mathrm{~m}$. The bottom layer is located 0,2-11 $\mathrm{m}$ from the top layer. Its thickness ranges from 0,1 to $8 \mathrm{~m}$, average $-5.69 \mathrm{~m}$, and the thickness of intermediate overburden $-11,0 \mathrm{~m}$. The average linear coefficient of two layers overburden together is 3,3 . Area of bottom layer distribution approximately $105,2 \mathrm{~km}^{2}$. The layer is mainly composed of poor sands, classified as non-industrial. The only exception is south-eastern part, where the bottom layer merges with the upper one. There are some of the balance reserves here (Galets'kyi et al., 2012).

The detailed exploration in the field is completed and calculated ore sand reserves by four versions of board content of standard ilmenite: 16; 20; 25; 35 $\mathrm{kg} / \mathrm{m}$ (according to Rutile-Ilmenite Company, Ltd, 2009). The low thickness of the covering rocks of the deposit provides open-pit method of the development. Deposit development is planned to start in the north-western part of the field due to overburden minimum thickness in this part of the deposit. 
This will help the company run as fast as possible and functioning at full capacity. According to project thickness and deposit reserves of $B+C_{1}$ categories the deposit development is expected for a period of 20 years. At the same time, $C_{2}$ category reserves and inferred resources the field will be developed at least for 30 years. The development of Tarasivka rutileilmenite-zirconium deposit with building and running of modern mining plant with the capacity of 5 million $\mathrm{m}^{3}$ per year will provide rutile, ilmenite, leucoxene and zircon concentrates (Galets'kyi et al., 2012).

Potential objects of Near-Azov (Southeast) region include Mazurivka feldspar-nepheline-rare ore deposit, Azov zirconium-rare earth ore deposit which is one of three largest fields in the world, and Anadolsky and Verbovy ore occurrences (rare earth) (Cherniyenko, 2006, 2008, 2010, 2013; Galets'kyi et al., 2012,). Mokroyalynka group of zircon and ilmenite placers (Mokroyalynka deposit) is also among the promising objects of the Azov region (Cherniyenko, 2013; Galets'kyi et al., 2012; Gurskyi et al., 2005). We will focus only on some of them.

Mazurivka deposit is a promising source of rare metals (niobium, tantalum, zirconium) and nepheline-feldspar products which production in the country either almost absent (niobium, tantalum) or is in insufficient amounts (nepheline-feldspar concentrate) (Cherniyenko, 2006, 2008, 2010, 2013; Galets'kyi and Cherniyenko, 2008; Galets'ky et al., 2009, 2012; Gurskyi et al., 2005).

The deposit is genetically linked to the Oktyabrsky alkaline massif development. Host rocks are

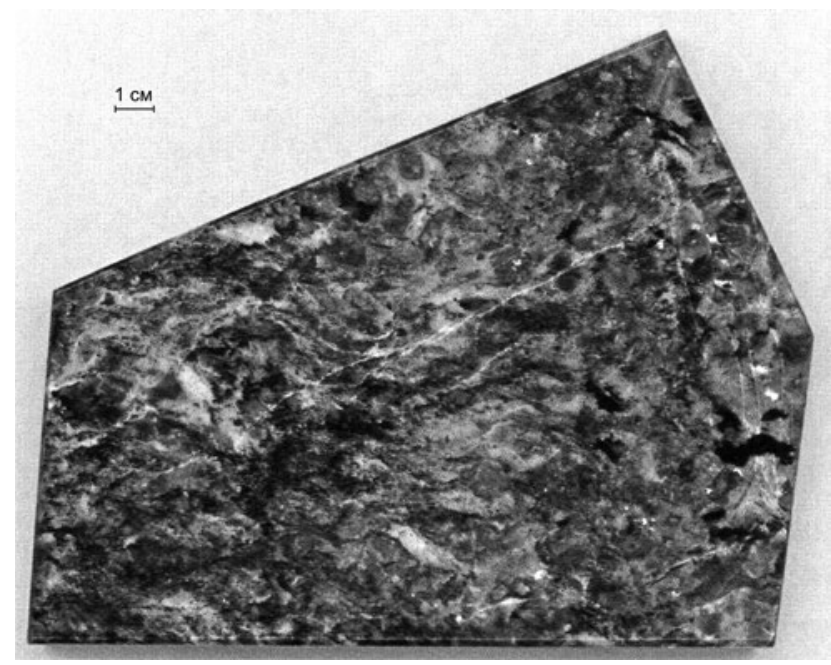

(a) basic-ultrabasic (gabbro, gabbro-pyroxenite, pyroxenite) that occur in the exocontact zone, mainly in the north and northeast of the massif. Structurally to a depth of $600 \mathrm{~m}$ the deposit is a series of subparallel shallow dipping ore bodies represented by mariupolite, microcline-nepheline pegmatite, feldspar metasomatite, rarely syenite-pegmatite. (Cherniyenko, 2006, 2008; Galets'ky et al., 2012).

In general, 44 ore bodies, including 10 ones within the detalization site, have been found on the deposit. More than 93\% of components reserves are concentrated in the bodies of the first and fifth depositions. Natural ore species percentage in the bodies is the following: mariupolite - 54\%; nepheline pegmatite - 24\%; feldspar metasomatite $20 \%$; enclosing rocks and products of their changes - 1,6-2\% (Fig. 2). Ore bodies have been traced over long distances, often more than $1000 \mathrm{~m}$. Their width is preferably greater than $300 \mathrm{~m}$, thickness is from 1 to $45-80 \mathrm{~m}$. Ore bodies contacts with enclosing rocks are clear, sharp, well visually mapped in the core of wells (Cherniyenko, 2006, 2008, 2010).

The field is related to geological economic type of rare metal albitite associated with nepheline syenite. The main economic ore type is disseminated, complex tantalum-niobium-zircon. Pyrochlore is the main carrier of tantalum and niobium, and zircon is the main carrier of zirconium.

Complex geological, laboratory and technical, economic studies found that Mazurivka deposit should be attributed to complex ore objects, as a promising source of rare metals (zirconium, niobium,

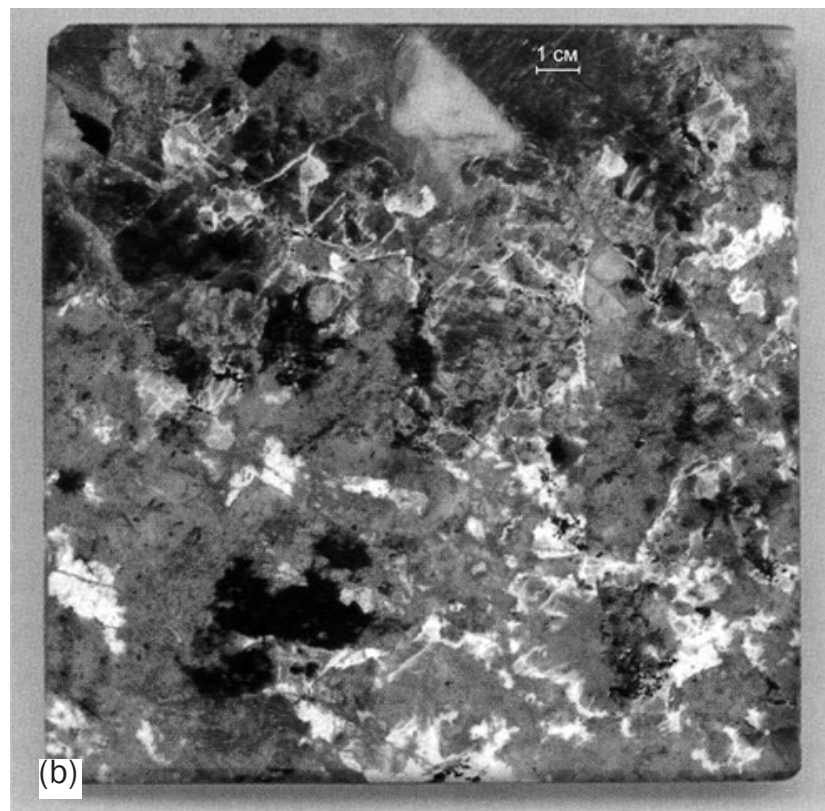

Fig. 2. Nepheline syenite (a) and mariupolite (b) of Mazurivka deposit Oktyabrsky alkaline massif (Cherniyenko, 2008). 
tantalum), high quality nepheline-feldspar concentrates for ceramics and silicon tetrachloride for the production of polysilicon, ferro aluminium products and coagulants. Currently the deposit is the most prepared object for commercial development (Atlas, 2007; Cherniyenko, 2006, 2008, 2010, 2013).

The Mokroyalynka deposit is located in the eastboard of Konksko-Yalynska depression. As a result of exploration of zircon and ilmenite placers in 1959 by Polevaya, Baranova, Borysenko for the first time were identified Manuyilsky, Novotatarsky Zlatoustivsky placers. The placer is intermittently stretching to the west of Manuyilsky fault. The main productive horizon is composed of sand and clay sediments of Novopetrivska suite of Miocene - inequigranular (fine-grained to coarse-grained, sometimes with pebbles) quartz sand, (rarely sandstones) with lenses and clay layers. Almost everywhere Novopetrivska suite deposits are covered by Neogene-Quaternary clays and loams. Facies analysis of sediments carried out by S. M. Strekozov (Strekozov, 1994) allowed to select two zones - external and internal. The external zone consists of deposits of river valleys with flat sides, floodplains, oxbow lakes and lakes. They are confined to the explored deposits: Novotatarsky, Manuyilsky and Zlatoustivsky. The internal zone consists of coastal-marine and marine sediments with "floating" coastline. Novotatarsky and Manuyilsky deposits are explored on a network of $100 \times 50 \mathrm{~m}$, Zlatoustivsky - from $200 \times 50$ to $100 \times 50 \mathrm{~m}$, calculated reserves of category $C_{1}$ for each of them. Productive layers of the area are diverse-grained horizons and coarse sand. Except quartz and clay minerals there are ilmenite, leucoxene, zircon, monazite, barite, magnetite, hematite, limonite, anatase, corundum, rutile, amphibole, sphen, biotite, tourmaline, muscovite, garnet, apatite and pyrite present in the sand. The distribution of zircon and ilmenite is uneven, its industrial concentration is confined mainly to the lower layers of sand. The highest concentrations are in the bottom of the horizon, where the content of zircon is $60 \mathrm{~kg} / \mathrm{m}^{3}$, ilmenite $200 \mathrm{~kg} / \mathrm{m}^{3}$. The average chemical composition of zircon: $\mathrm{SiO}_{2}-31,3 \%, \mathrm{ZrO}_{2}-$ $62,6 \%, \mathrm{TiO}_{2}-1,0 \%, \mathrm{Fe}_{2} \mathrm{O}_{3}-1,5 \%$; $\mathrm{HfO}_{2}-1,2 \%$; $\mathrm{CaO}-$ $0,9 \%$. The chemical composition of ilmenite: $\mathrm{TiO}_{2}-$ $61,3 \%, \mathrm{Fe}_{2} \mathrm{O}_{3}-31,4 \%, \mathrm{SiO}_{2}-1,5 \%, \mathrm{MnO}-1,25 \%$, $\mathrm{Nb}_{2} \mathrm{O}_{5}-0,015 \%, \mathrm{CaO}-0,8 \% \mathrm{MgO}-1,9 \%, \mathrm{P}_{2} \mathrm{O}_{5}-$ $0,14 \%$. Placer reserves are: zircon - 71555 tons, ilmenite - 423500 tons (Galets'kyi et al., 2012; Gurskyi et al., 2005).

Neutron activation analysis carried out by V.V. Vasilchenko (Vasilchenko et al., 1989) showed a high content of scandium in zircon of Novotatarsky placer $(0,0123-0,02 \%, 0,0157 \%$ average) and ilmenite (0,0033-0,0038\%, 0,0036\% average). It allowed to calculate the forecast resources of scandium in Novotatarsky, Manuyilsky and Zlatoustivsky deposits in the amount of 26,5 tons. The high concentrations of scandium in major placer minerals significantly increase the commercial value of these placers (Galets'kyi et al., 2012).

Within a band of marine sediments has been allocated a placer area - deposits of littoral-marine facies with the highest saturation of productive layers (sand horizons with zircon content of $\geq 2 \mathrm{~kg} /$ $\mathrm{m}^{3}$ with an average of more than $\left.3,5 \mathrm{~kg} / \mathrm{m}^{3}\right)$. The length of placer zone is $30 \mathrm{~km}$, width $-12 \mathrm{~km}$, the total area is $240 \mathrm{~km}^{2}$. Within the zone the productive layers are marked, which correspond to three hypsometric horizons: more than $+150 \mathrm{~m}$, interval $+149-+131 \mathrm{~m}$, and less than $+130 \mathrm{~m}$. It is identified 61 productive layers of lenticular, clustered and bifurcated lenticular form within the zone. The most common thickness is 4,0-9,0 m. The average content of zircon is up to $5 \mathrm{~kg} / \mathrm{m}^{3}$ in 38 layers, $5-10 \mathrm{~kg} / \mathrm{m}^{3}-22$ layers, more than $10 \mathrm{~kg} / \mathrm{m}^{3}-$ one layer. The average content of ilmenite is $20 \mathrm{~kg} / \mathrm{m}^{3}$. The layers are grouped into ten multilayered placers. An example is the multi-layered placer 8 consisting of 18 productive layers. The average thickness of the ore layer is $4,7 \mathrm{~m}$, the total average thickness of ore layers - 59,3 m, interstratal exposure (clay, clayey sands) $-22,8 \mathrm{~m}$, the depth of the ore roof layer is more than $22 \mathrm{~m}$ from the surface. Average content of zircon is $5,68 \mathrm{~kg} / \mathrm{m}^{3}$, ilmenite $38,59 \mathrm{~kg} / \mathrm{m}^{3}$ (Galets'kyi et al., 2012).

The significance of zircon-ilmenite placers of Mokroyalynka deposit can be enhanced by concomitant removal of impurity elements: scandium, hafnium, niobium and vanadium. It is possible to get the other products from the light fraction of ore layers and overburden that raise profitability of these placers development. All of the above suggests that within the placer area of Mokroyalynka deposit the continuation of exploration is necessary. In addition, the increased zircon contents were found in kaolin sand in neogenic mottled clays - 0,39, 0,43 and $0,78 \mathrm{~kg} / \mathrm{m}^{3}$. The search for placers in these sediments were not carried out, and a detailed study may identify coastal-marine placers of Sarmatian or Pontian age (Galets'kyi et al., 2012).

The interest in placers of coastal marine genetic type as a source of raw zircon, ilmenite and other minerals increased because they can be de- 
veloped more quickly and at lower economic costs compared with deposits of other genetic types. This allows to engage in the development the relatively small-scale deposits and the content of useful components in ores will need less requirements (Galets'kyi et al., 2012; Gurskyi et al., 2005).

\section{CONCLUSIONS}

Out of Ukraine's economy from the crisis on the basis of restructuring can be done in the short term based on the capacity of the state: rich labor and natural resources, main production facilities, communications and to attract investment in mineral complex. Thus, it is extremely important to the efficient and effective use of mineral resources and strict legislation regulating relations in the field of mineral resources of Ukraine.

In a competitive environment, manufacturers of rare-products that have their own sources of minerals have significant advantages. They are relatively free in the formation of prices for raw materials, in-

\section{REFERENCES}

Cherniyenko N.N., 2006. Geological and technological features of the Mazurovka field development of the Nea-Azov. Geological journal (Heolohichnyi jurnal), No 2-3. Pp. $191-$ 197. (In Russian).

Cherniyenko N.M., 2008. Geological and economical criteria integrated development of Mazurivka deposit of feldspar-nepheline and rare-metal ores within the Near of Azov. Ukrainian Geologist (Heoloh Ukrayiny), No 3-4. Pp. 40-51. (In Ukrainian).

Cherniyenko N.N., 2010. A few comments on the Mazurovka or invitation to the settings dialog. Ukrainian Geologist (Heoloh Ukrayiny), No 1-2. Pp. 133-136. (In Russian).

Cherniyenko N.N., 2013. Geological and Economic Assessment of Rare Metals Deposits and Rare Earth Elements of the Ukrainian Shield for their Priority Development. The 5th International scientific conference of young scientists and students "Fundamental and applied geological science: Achievements, Prospects, Problems and Ways of the Solutions". The conference's Abstract. November 14-15. Baku. Azerbaijan. Pp. 75-76.

Galets'kyi L.S. (Editor-in-Chief), 2007. An Atlas of Geology and Mineral Resources of Ukraine. Toronto, University of Toronto Press, $168 \mathrm{p}$.

Galetskyi L.S, Cherniyenko N.N., 2008. The state and prospects of providing Ukraine's mining and metallurgical complex with mineral raw materials. Ukrainian Geologist (Heoloh Ukrayiny), No 4. Pp. 27-38. (In Russian).

Galets'kyi L., Cherniyenko N., Remezova O., Nastenko O, Kovryzhenko L. (Romaniuk), 2015. Priority measures to im- termediate and end products. Therefore, access to sources of cheap raw materials is one of the main conditions to reduce the cost of production. Need to create their own rare-rare earth industry, the production of end products and products. This perspective will enable not only occupy a worthy economic and strategic position in the market but, above all, to develop and provide their own domestic market. As a result, the country will go to a vicious cycle of production, from mining to create high-quality products of new generation. The high metallogenic potential in Ukraine on rare metals and rare earth elements makes it possible to build a new high-tech production on the international standards level.

Therefore, the creation of rare metals industry in Ukraine is not just a start for the development of the internal market, creating a modern competitive products, revival of electronic, electrical industry. It is also the introduction of new technologies, "intellectual design industry" a new space age, building completely new Economy intellectual level.

Черниенко Н.Н. Геолого-технологические особенности освоения Мазуровского месторождения Приазовья. Геологічний журнал. 2006. № 2-3. С. 191-197.

Чернієнко Н.М. Геолого-економічні критерії комплексного освоєння Мазурівського родовища польовошпат-нефелінрідкіснометалевих руд Приазов'я. Геолог України. 2008. № 3-4. C. 40-51.

Черниенко Н.Н. Несколько замечаний по поводу Мазуровки или приглашение к Аиалогу. Геолог України. 2010. № 1-2. С. 133-136.

Cherniyenko N.N. Geological and Economic Assessment of Rare Metals Deposits and Rare Earth Elements of the Ukrainian Shield for their Priority Development. The 5th International scientific conference of young scientists and students "Fundamental and applied geological science: Achievements, Prospects, Problems and Ways of the Solutions". The conference's Abstract. November 14-15. Baku. Azerbaijan. 2013. Pp. 75-76.

An Atlas of Geology and Mineral Resources of Ukraine. Editor-in-Chief Galets'kyi L.S. [ISBN-10:0-8020-8989-5. - ISBN13:978-0-8020-8989-2.]. Printed in Canada. Publisher Toronto: University of Toronto Press, 2007. 168 p.

Галецкий А.С., Черниенко Н.Н. Состояние и перспективы обеспечения ГМК Украины минеральным сырьем. Геолог України. 2008. № 4. С. 27-38.

Галецький А.С., Чернієнко Н.М., Ремезова О.О., Настенко О.М., Ковриженко (Романюк) ^.С., 2015. Першочергові за- 
prove the subsoil in Ukraine. Second International Scientific-Practical Conference "Subsoil use in Ukraine. Prospects for Investment" (5-8 October 2015). Truskavets, Ukraine. Pp. 202-205. (In Ukrainian).

Galets'kyi L.S., Cherniyenko N.M., Dyschuk M.U., Kohan E.Sh., Romaniuk L.S., Kuzmanenko I.L., Vasylenko S.P., Hruba V.V., Mazko M.I., 2012. Definition and geological-economic assessment of the priority fields of rare metals and rare earth elements of Ukrainian shield for their priority development. The report on the research work for 2009-2012. Kyiv. Department of Economic Geology, Institute of Geological Sciences of Ukraine. 157 p. (In Ukrainian).

Galets'kyi L.S., Romaniuk L.S., 2011. Geological and geochemical conditions of formation of Perzhansk genthelvite deposits. Proceedings of the Ukrainian Mineralogical Society (Zapysky ukrainskoho mineralohichnoho tovarystva), Kyiv. Volume 8. Pp. 41-45. (In Ukrainian).

Galets'kyi L.S., Cherniyenko N.M., Naumenko U.Z., Kovryzhenko L.S., 2016. The preparation for industrial development Perga deposits of rare metals. Problems and prospects of the geology development: science and production. Proceedings of the International Geology Forum (15-20 August 2016). Koblevo, Mykolaiv region, Ukraine. Kyiv. UkrSGRI. Pp. 41-46. (In Ukrainian).

Galets'kyi L.S, Naumenko U.Z., Cherniyenko N.M., 2016. Main types of ore-bearing structures of Ukraine. Problems and prospects of the geology development: science and production. Proceedings of the International Geology Forum (15-20 August 2016). Koblevo, Mykolaiv region, Ukraine. Kyiv. UkrSGRI. Pp. 35-40. (In Ukrainian).

Galetsky L.S., Naumenko U.Z., Cherniyenko N.M., 2011. Geological and structural conditions ore concentration on the territory of Ukraine. Scientific principles of geological-economic estimation of the mineral resource base of Ukraine and the world: proceedings of the international scientific conference. Kyiv, Nika-Tsentr, 2011. Pp. 14-16. (In Ukrainian).

Galets'kyi L.S., Yakovlev Eu.A., Cherniyenko N.M., 2009. The changing role and value of the mineral resource potential of Ukraine in modern conditions. National security: Ukrainian dimension. Quarterly scientific journal. The national security Council and defense of Ukraine, Institute of problems of national security; editorial Board: Horbulin V.P. (editor in chief). Kyiv. Vol. 4 (23). Pp. 32-38. (In Ukrainian).

Gurskyi D.S., Chornokur I.G., 2009. Perzhansk beryllium deposit (geology and exploration prospects in the context of global and domestic trends of the mineral resource base of rare metals). Mineral Resources of Ukraine (Mineralni Resursy Ukrayiny), No 4. Pp. 22-32. (In Ukrainian).

Gurskyi D.S., Esypchuk K.E., Kalinin V.I., Kulish E.A., Nechaev S.V., Tretyakov U.I., Shumlyanskyi V.A., Bakardzhyev A.H., Lebed' N.I., Makivchuk O.F., 2005. Mineral deposits of Ukraine. Volume 1. Metallifereous mineral deposits. Kiev-Lvov. Centre Europe. Pp. 427-429. (In Russian).

Naumenko V.Z., 2014. Regarding the geological structure and development history Sushchano-Perzhansk fault zone. Problems of Geology of the Phanerozoic of Ukraine: Materials of the $V$ all-Ukrainian scientific conference (8-10 October 2014). Lviv. Pp. 133-136. (In Ukrainian). ходи по покращенню надрокористування в Україні. Аруга міжнародна науково-практична конференція "Надрокористування в Україні. Перспективи інвестування" (5-8 жовтня 2015 р.). Трускавець, Україна. 2015. С. 202-205.

Галецький ^.С., Чернієнко Н.М., Аищук М.Ю., Коган Є.Ш., Романюк ^.С., Кузьманенко І.^., Василенко С.П., Груба В.В., Мазко М.І. Визначення та геолого-економічне обгрунтування пріоритетних родовищ рідкісних металів та рідкісноземельних елементів Українського щита Аля їх першочергового освоєння. Звіт про науково-дослідну роботу за 2009-2012рр. Київ. ВідАіл геології корисних копалин, ІГН НАН України. 2012. 157 с.

Галецький ^.С., Романюк ^.С. Геолого-геохімічні умови формування Пержанського родовища гентгельвіну. Записки українського мінералогічного товариства. Київ. 2011. T. 8. C. $41-45$.

Галецький ^.С., Чернієнко Н.М., Науменко У.З., Ковриженко ^.С. Перспективи промислового освоєння Пержанського родовища рідкісних металів. Актуальні проблеми та перспективи розвитку геології: наука й виробництво. Матеріали Міжнародного геологічного форуму (15-20 серпня 2016 р.). Коблеве, Миколаївська обл., Україна). К.: УкрАГРІ. 2016. С. 41-46.

Галецький ^.С., Науменко У.З., Чернієнко Н.М. Основні типи рудоносних структур України. Актуальні проблеми та перспективи розвитку геології: наука й виробництво. Матеріали Міжнародного геологічного форуму (15-20 серпня 2016 р.). Коблеве, Миколаївська обл., Україна). К.: УкрАГРІ. 2016. С. 35-40.

Галецький ^.С., Науменко У.3., Чернієнко Н.М. Геологоструктурні умови рудоконцентрації на території України. Наукові засади геолого-економічної оцінки мінеральносировинної бази України та світу: тези міжнародної наукової конференції. К.: Ніка-Центр, 2011. С. 14-16.

Галецький ^.С., Яковлєв Є.О., Чернієнко Н.М. Зміна ролі і значення мінерально-сировинного потенціалу України в сучасних умовах. Національна безпека: український вимір: щоквартальний науковий збірник. Рада національної безпеки і оборони України, Інститут проблем національної безпеки; редколегія: Горбулін В.П. (голов. реА.) [та ін.]. К. 2009. Вип. 4 (23). С. 32-38.

Гурський А.С., Чорнокур І.Г. Пержанське родовище берилію (геологія та перспективи освоєння в контексті світових і вітчизняних тенденцій розвитку мінерально-сировинної бази рідкісних металів). Мінеральні ресурси України. 2009. № 4. C. 22-32.

Гурский А.С., Есипчук К.Е., Калинин В.И, Кулиш Е.А., Нечаев С.В., Третьяков Ю.И, Шумлянский В.А., БакарАжиев А.Х., Лебедь Н.И., Макивчук О.Ф. Метаммические и неметамлические полезные ископаемые Украины. Т 1. Метамлические полезные ископаемые. Киев-львов. Изаво «Центр Европы". 2005. С. 453-454.

Науменко У.З. Щодо геологічної будови та історії розвитку Сущано-Пержанської розломної зони. Проблеми геології фанерозою України: Матеріали V Всеукраїнської наукової конференції (8-10 жовтня 2014 р.). Мьвів. 2014. с. $133-136$. 
Romaniuk L.S., 2010. Peculiarities of formation and mineralogical composition of Perzhansk tinstone-columbite placer. Collection of scientific works of the IGS NAS of Ukraine. Vol. 3. Pp. 338-342. (In Ukrainian).

Romaniuk L., 2010. Alkane feldspar metasomatites of the Sushchano-Perzhansk zone of activation of the Ukrainian shield. Alkane rocks: petrology, mineralogy, geochemistry. Proceedings of the International scientific Conference dedicated to the memory of J.A. Morozewicz (19-21 September). Kyiv. Ukraine. Pp. 54-55.

Romaniuk L.S., 2013. Geological-structural position of Perzhansk rare metal district. Geological Journal (Heolohichnyi jurnal), No 2. Pp. 37-42. (In Ukrainian).

Romaniuk L., Cherniyenko N., 2013. The geological position of Perzhansk ore district withing the boundaries of SushchanoPerzhansk zone of activation. Proceedings of the Fifth Ukrainian scientific Conference of young scientists on the 95-th anniversary of the National Academy of Sciences of Ukraine. (19-20 November). Kyiv. Ukraine. 59 p. (In Ukrainian).

Vysotskyi B.L., Metalidi V.S., Pryhodko V.L., Lykov L.I., Popov R.L., 2003. Geological structure, ore bearingness and prospects of Perzhansk ore field deposits exploitation. Geological and Mineralogical Journal Kryvyi Rih Technical University (Heoloho-Mineralohichnyi jurnal), No 2. Kryvyi Rih Technical University. Pp. 73-74. (In Ukrainian).
Романюк ^.С. Особливості формування та мінералогічного складу Пержанських каситерит-колумбітових розсипів. Збірник наукових праць ІГН НАН України. 2010. Вип. 3. с. $338-342$.

Romaniuk L. Alkane feldspar metasomatites of the Suschany-Perga zone of activation of the Ukrainian shield. Alkane rocks: petrology, mineralogy, geochemistry. Proceedings of the International scientific Conference dedicated to the memory of J.A. Morozewicz (19-21 September). Kyiv. Ukraine. 2010. Pp. 54-55.

Романюк ^.С. Геолого-структурна позиція Пержанського рідкіснометалевого району. Геологічний журнал. 2013. № 2. C. $37-42$.

Романюк ^., Чернієнко Н. Геологічна позиція Пержанського рудного району в межах Сущано-Пержанської зони активізації. Збірник матеріалів П'ятої Всеукраїнської наукової конференції молодих вчених Ао 95-річчя Національної академії наук України (19-20 мистопада, 2013 р.). Київ. Україна. С. 59.

Висоцький Б.^., Металіаі В.С., Приходько В.^., Аиков А.І., Попов Р.^. Геологічна будова, рудоносність та перспективи освоєння родовищ Пержанського рудного поля. Геологомінералогічний вісник Криворізького технічного університету. 2003. № 2. ВиАавничий центр Криворізького технічного університету. С. 73-74.

\section{Н.Н. Черниенко}

\section{ГЕОЛОГО-ЭКОНОМИЧЕСКОЕ ОБОСНОВАНИЕ И ПЕРСПЕКТИВЫ РАЗВИТИЯ МИНЕРАЛЬНО-РЕСУРСНОЙ БАЗЬ РЕАКИХ МЕТАМОВ УКРАИНЫ В СОВРЕМЕННЫХ ЭКОНОМИЧЕСКИХ УСЛОВИЯХ}

Состояние производительных сил в минерально-сырьевом комплексе Украины на современном этапе ее политического, экономического и социального развития определяется рядом факторов: особенностями минерально-сырьевой базы, направленностью экспортно-импортной политики, состоянием рыночных отношений, экономическими приоритетами, возможностью удовлетворять сырьевые потребности за счет собственных минеральных ресурсов основываясь на новейших Аостижениях в области создания и внеАрения мало- и безотходных технологий при добыче, обогащении, переработке природных и техногенных виАов минерального сырья. На примере Пержанского рудного района, Тарасовского, Мазуровского, Мокроялынского месторожАений рассмотрены перспективы развития минерально-сырьевой базы редких метамлов и реАких земель в Украине, которые в современном мире являются показателем научно-технического уровня развития страны. Опережающее развитие редкометальной промышленности способно Аать стране значительный экономический эффект за счет сокращения энерго- и материалозатрат, способствовать развитию горнодобывающей промышленности, обеспечить выхоА из современного Аепрессивного состояния отАельных регионов Украины и их экономическое развитие на протяжении многих десятилетий. Ключевые слова: Украинский щит, горнорудный район, редкие метамлы, месторождение, россыпи. 